\title{
MAST CELLS IN THE MENINGES OF NECTURUS, EASILY MISTAKEN FOR NERVE CELIS
}

\author{
PAUL S. MCKIBBEN \\ The Anatomical Laboratory of the Western University of London, Ontario \\ TWO FIGURFS
}

In the study of the nervus terminalis of Necturus maculosus, attention has already been called (McKibben '11) to mast cells, the "clasmatocytes of Ranvier," as they exist in the nasal region and in the meninges of this amphibian. The purpose of the present paper is not to attempt a description of these cells but rather to call attention to the fact that they may be easily mistaken for nerve cells when treated by some histological and neurological methods.

As is indicated in figure 1, these mast cells occur in great numbers in the dura mater. They are found also in the other meninges, along the olfactory nerve and about the nasal sac, as well as in the mesenteries and in the subcutaneous tissue where they were first described.

The cells in question (fig. 2) are elongated, irregular cells, usually with several long cytoplasmic processes. The nuclei of these cells seem poor in chromatin, taking a very feeble stain with basic dyes; but the cytoplasm surrounding the nuclei and that forming the long branching processes is seen to contain sharp granules which exhibit metachromatism. These cells, the "clasmatocytes of Ranvier" (Ranvier '90, '93, '00) as described in Amphibia, have been shown by Jolly ('00) and by Maximow ('02, '06) to be identical with mast cells although of peculiar form. In Mammalia, where no similarity in form between the mast cells of Ehrlich and the clasmatocytes exists, the confusion is impossible. 
In figure 1, a drawing made from a whole mount of the dura mater of Necturus, the form, frequency and extent of the mast cells are shown. Their similarity to certain sympathetic nerve cells, in shape, size and extent, might lead one into serious error. That these are not nerve cells has been demonstrated thus: first,

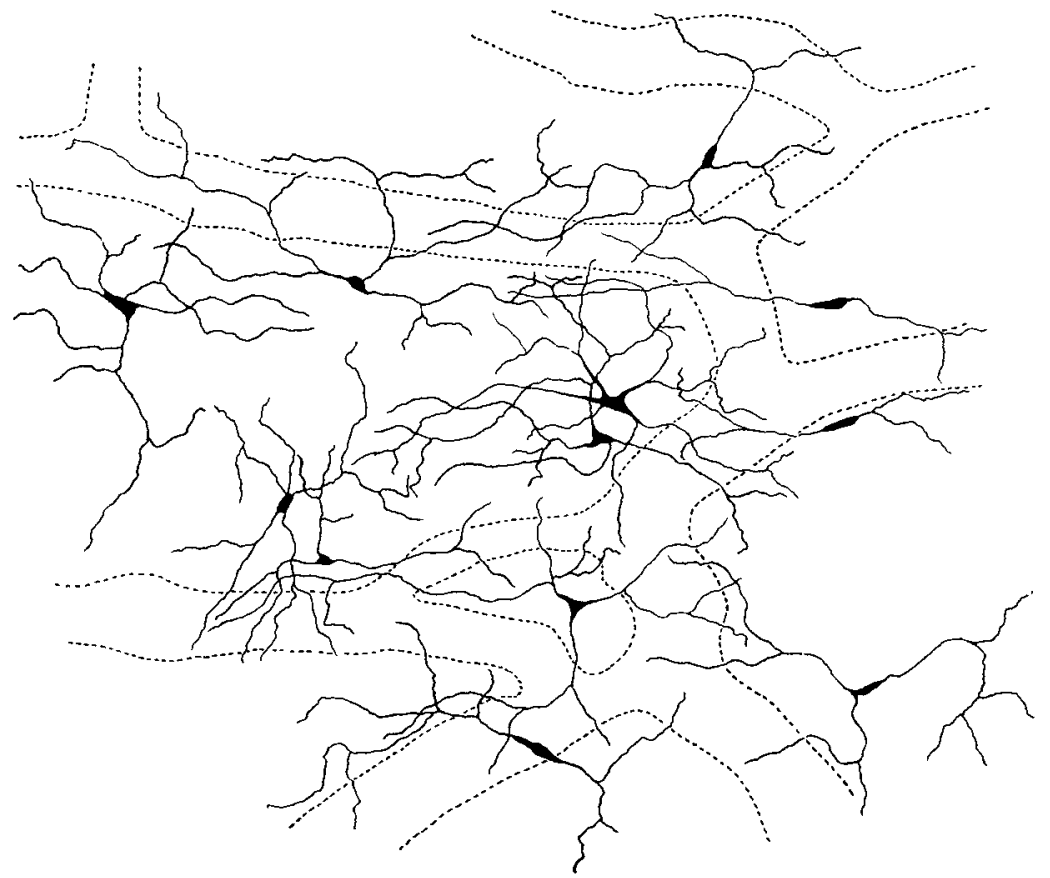

Fig. 1 Drawing, made with camera lucida, of the dura mater taken from the roof of the cranial cavity of Necturus; a whole mount of the dura mater fixed in formaline-Zenker's fluid and stained with Wright's stain. The blood capillaries are indicated by the dotted lines. $\times 70$.

the cytoplasmic granules have a different form and arrangement from that exhibited by the Nissl granules of nerve cells; second, they will stain intra-vitam with methylene blue and when so stained show the characteristic metachromatic tint; third, when treated with sulphuric acid and aqueous hematoxylin these granules fail to show the presence of iron which is characteristic of the Nissl granules of nerve cells. In these tests for iron, control 
sections, known to contain nerve cells with Nissl granules, received exactly the same treatment as the sections containing the mast cells; so that the failure of the granules of the mast cells to react for iron was due, probably not to faulty technique, but to their chemical composition, when the Nissl granules in the same experiment gave the typical reaction.

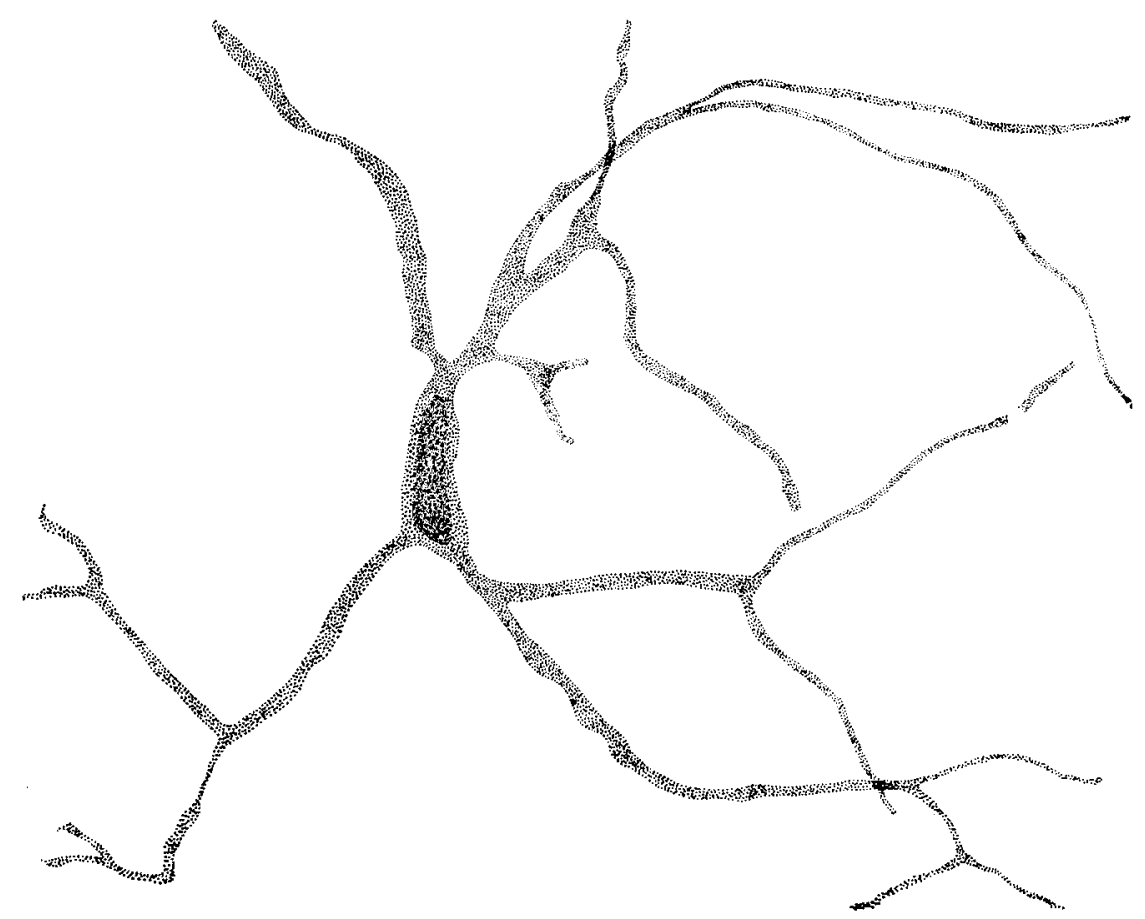

Fig. 2 Drawing, made with camera lucida, of a single mast cell in the dura mater from the floor of the cranial cavity of Necturus; a whole mount of the dura mater fixed in Formaline-Zenker's Fluid and stained with toluidine blue. $\times 450$.

Under certain conditions and in certain tissues, treatment of these mast cells in amphibia by the Golgi impregnation method, by the Cajal silver method and its modifications and by other methods, gives a picture in which it is well nigh impossible to determine whether one is dealing with sympathetic nerve cells or with these branched mast cells. Consequently in a study 
in amphibia of certain tissues where sympathetic nerve cells and these mast cells may occur simultaneously, when methods are used by which it is impossible to differentiate between the two types of cells, the value of the observations is open to question. In Mammalia a similar confusion of nerve cells and certain cells of connective tissue is not altogether impossible.

The author wishes here to acknowledge his indebtedness to Professor R. R. Bensley and to the Anatomical Laboratory of the University of Chicago for assistance in this and other work.

\section{LITERATURE CITED}

Cerlettr, Ugo 1911 Die Mastzellen als regelmässiger Befund im Bulbus olfactorius des normalen Hundes. Folia Neurobiologica, Bd. 5, Nr. 7.

Jolny 1900 Clasmatocytes et Mastzellen. C. R. Soc. de Biol., pp. 609-611, 1900 .

Maximow, Alexander 1902 Experimentelle Untersuchungen über die entzündliche Neubildung von Bindegewebe. Beiträge path. Anat. u. allge. Path. Ziegler, sup. 5.

1906 Ueber die Zellformen des lockeren Bindegewebes. Areh. mikr. Anat. u. Entwick., Bd. 67, p. 680.

McKibien, PaUl S. 1911 The nervus terminalis in Urodele amphibia. Jour. Comp. Neur., vol. 21, no. 3.

Phisalix, C. 1900 Sur les clasmatocytes de la peau de la Selamandra terrestre et de sa larve. Bul. Mus. Hist. nat., pp. 72-75.

Ranvier,'L. 1900 Des clasmatocytes. Arch. d'anat. micr., vol. 3, p. 122. 